\title{
STUDENTS' DIFFICULTIES IN USING SIMPLE PRESENT TENSE: A CASE STUDY AT SENIOR HIGH SCHOOL
}

\author{
Rusdin \\ STKIP Yapis Dompu \\ Nusa Tenggara Barat, Indonesia \\ surflakey@gmail.com
}

\begin{abstract}
This study aims to determine the problems faced by second grade students in using the simple present tense at (Madrasah Aliyah Negeri) MAN Dompu. The data collection used in this research is interviews and tests, in order to find and classify the problems faced by second grade students who have difficulty using the simple present tense. The research method used in this research is descriptive qualitative and quantitative methods. The population used in this study consisted of 5 classes and the sample was taken randomly, eight students in each class were used as samples. The number of samples is 40 students. The results of data analysis obtained through object tests and essay tests show that students' scores are very poor. This is evidenced by the average value of students is 3.9. Based on the test results, it shows that students have low ability in using the simple present tense, the students are quite interested in English subjects; English is very difficult for them; English teachers never give advice and motivation to students; the teacher never informs the students about the importance of learning English, especially the simple present tense; students have low motivation in learning English; English teachers never pay attention to students who have difficulty learning English; lack of stimulation for students in learning English; and students have low abilities. The researcher hopes that this research can contribute to teachers and students in the teaching and learning process of English, especially in the use of the simple present tense.
\end{abstract}

Keyword: The student's difficulties, simple present tense, tenses.

\section{INTRODUCTION}

English grammar must be understood by students in high school. In this study, the English grammar studied was simple present tense. Based on the high school syllabus, the simple present tense is taught in the second grade and has been learned by students when they are still in junior high school. In this case, the teacher must strive to train and stimulate students' skills including social functions, generic structures and also lexicogrammatical features. Generally the students are demanded to understand and to memorize the formulas of structure or grammar, but they cannot apply them in writing or in speaking and it becomes one of the problems for them. (Rezi \& Al Hafizh, 2020). Correlate to this research, the researchers only specialize in simple tense. It can help the students a way to use appropriate grammar once they speak and write in English. Students who have good competence in grammatical are going to be easy to grasp about English, such as creating a sentence, speaking, and writing 
one another. According to (Sabra, 2020: 02) The verb often describes what happens or what someone does, and in the English language the verb varies in forms according to when something happens or when someone does something. Furthermore, (Sabra, 2020: 145) states that Grammar should be comprehended by the learners at the school. Based on the syllabus of senior high school, simple present tense and simple past tense are taught at the first grade and it has been learned by the students when they were in junior high school. In learning simple present, the teaching-learning process focuses on grammar use and its intonation, if one asks the common speaker of a language what they comprehend of grammar, they will remember the previous lesson from school, but beyond that, they are going to say that they need forgetting what grammar they once knew. (Michael Swan, 1984: 206) explains that We can also use the simple present to talk about 'momentary' present actions things which take a very short time to happen. (e.g. Lydiard passes to Tylor, Taylor to Morrison, Morrison back to Taylor: ...and Taylor shoots and it's a goal!!!). Since the knowledge of grammar is essential for competent users of a language, it's necessary for the student. Hence, (Hummel \& James, 1986) argue that the present tense is into three categories: first, the simple present tense which indicates a habitual or repeated action, second, the progressive which indicates an ongoing or incomplete action, and third the emphatic response. Thus, as an example they have to grasp that verbs in person singular have an "s" ending within the present simple e.g., he swims, doesn't he? She never sees it, does she? While the utilization of to be must be suited with its subject except; I'm a student, aren't I? the student also must know that modal auxiliaries are followed by bare infinitives without "to" sat that, they'll eventually avoid making mistakes like "he must travel, mustn't he?. Students have to bear in mind this, even as they have to bear in mind all language possibilities. Such awareness doesn't mean that they need to be taught each variation and linguistic cycle. However, it just implies that they need to bear in the mind language and the way it's used.

Based on the results of observations on the second grade students of MAN Dompu for English subjects, it shows that students face many difficulties in understanding and learning English grammar, especially in the use of the simple present tense. Realizing the difficulties faced by Dompu MAN students in learning English grammar about the use of tenses (simple present tense), the problems faced 
by students need to be analyzed. By analyzing the students' ability to understand the use of the simple present tense, it will help to find out the factors that make it very difficult for students to understand the use of the simple present tense. To assist students in understanding the correct use of the simple present tense both in speaking and writing. Students who have good grammatical competence will easily understand English, such as making sentences, speaking, and writing with each other. Based on the explanation above, the researcher is interested in analyzing the difficulties of the second graders of MAN Dompu in understanding the use of the simple present tense in both speaking and writing.

\section{Purpose and Research questions}

Regarding the study, the formulation of the problems of this study can be formulated as follows:

RQ1. How is the student's ability in learning simple presents?

RQ2. What difficulties do face the students have in learning simple presents?

\section{METHOD}

The research method used in this research is descriptive qualitative and descriptive quantitative. Best and Khan (1986:12) state that descriptive research, sometimes known as non-experimental or correlation research, is concerned with the relationships between variables, and also the development of generalizations, principles, or theories that have universal validity. This research is descriptive evaluative, where this research activity aims to determine the facts at a certain time and use the findings to determine the effectiveness, utilization of the process, product or program being studied. So, in this research, the aim is to find out the description of students' difficulties in learning English, especially in writing material using the simple present tense in second grade students of MAN Dompu.

\section{Population and Sample size \\ Population}

The populations of this research were the second-year students of MAN Dompu in the academic year 2021/2022, which consists of 5 classes. IPA I consists of 38 students, IPA II consists of 36 students, IPS I consists of 36 students, IPS II consists of 36 students and Agama consists of 38 students. The total numbers of population were 184 students.

\begin{tabular}{ccccc}
\hline No & Class & \multicolumn{2}{c}{ Students } & Quantity \\
& & Male & Female & \\
$\mathbf{1}$ & IPA I & 17 & 21 & $\mathbf{3 8}$ \\
$\mathbf{2}$ & IPA II & 14 & 22 & $\mathbf{3 6}$ \\
$\mathbf{3}$ & IPS I & 19 & 17 & $\mathbf{3 6}$ \\
$\mathbf{4}$ & IPS II & 15 & 21 & $\mathbf{3 6}$ \\
$\mathbf{5}$ & Agama & 16 & 22 & $\mathbf{3 8}$ \\
\cline { 5 - 5 } & & &
\end{tabular}




\begin{tabular}{cccc}
\hline Total & 81 & 103 & 184 \\
& Table & 1 & Research Population \\
\hline
\end{tabular}

\section{Sample}

Considering the few numbers of the population, the researcher take a sample randomly, took eight students in each class for the sample. In total, the sample was 40 students.

\begin{tabular}{|c|c|c|c|}
\hline No & Class & $\begin{array}{l}\text { Number of } \\
\text { Students }\end{array}$ & $\begin{array}{c}\text { Samples } \\
(\mathbf{3 2 \%})\end{array}$ \\
\hline 1 & IPA I & 38 & 10 \\
\hline 2 & IPA II & 36 & 7 \\
\hline 3 & IPS I & 36 & 6 \\
\hline 4 & IPS II & 36 & 7 \\
\hline 5 & Agama & 38 & 10 \\
\hline \multicolumn{2}{|c|}{ Total } & 184 & 40 \\
\hline
\end{tabular}

\section{Instrumen}

The instruments used in this study were two kinds of instruments, namely: questionnaires, and objective tests. The questionnaire used was to find out the difficulties of second graders of man dompu in using the simple present tense. The test used is to measure students' difficulties in understanding the use of the simple present tense.

\section{Data Collection}

In collecting the data, the researcher used the subsequent procedures:

1. After getting permission for taking an inquiry, the researcher came to the category to start the research.
2. The researcher distributed a test of English that focused on the simple present tense.

3. Then, the researcher continued to distribute the questionnaire about the difficulties faced by the student in learning simple present tense.

To analyze the result of the test, the researcher used the mean score's formula to assess the student mean score in the simple present tense. The finding of this research was explained descriptively.

To calculate the student mean score, the researchers used the subsequent descriptive formula:

$$
\times=\frac{\sum \times}{n}
$$

Where :

$\mathrm{X}=$ mean score

$\Sigma \times \quad=$ the sum of all score

$\mathrm{N}=$ total number of subject

(Gay, 1986: 298)

To find out the rate percentage of students' scores, the researchers used this formula to analyse the data.

$\%=\times 100 \%$

Where: $\frac{n}{N}$

$\mathrm{n}=$ Frequency

$\mathrm{N}=$ the total number of student

(Arikunto, 1991:182).

To find out the student's grade, the researchers used this formula to analyze the data of scores. 


$$
x 10=\text { grade }
$$

Where: $\frac{\text { Score }}{\text { Total score }}$

\begin{tabular}{|c|c|}
\hline Score & $\begin{array}{l}=\text { the student's score of } \\
\text { the test result }\end{array}$ \\
\hline $\begin{array}{l}\text { Total } \\
\text { score }\end{array}$ & $\begin{array}{l}=\text { number of the score of } \\
\text { all the test items }\end{array}$ \\
\hline Ten & $\begin{array}{l}=\text { maximal grade if all the } \\
\text { test items are answered } \\
\text { correctly }\end{array}$ \\
\hline & $=$ the student's value \\
\hline
\end{tabular}

score and the number of test items of the simple present in this research is 30 items. So, the total score of the test is 30 . The score of achievement category is classified as follows:

\begin{tabular}{llc}
\hline No & Achievement & Range of Score \\
1 & Excellent & $9.6-10$ \\
2 & Very good & $8.6-9.5$ \\
3 & Good & $7.6-8.5$ \\
4 & Fairly good & $6.6-7.5$ \\
5 & Fair & $5.6-6.5$ \\
6 & Poor & $3.6-5.5$ \\
7 & Very poor & $0-3.5$ \\
\hline \multicolumn{2}{c}{ Table 3 Achievemwnt Category }
\end{tabular}

While the analysis of information taken through the questionnaire to understand the student's response in learning simple present was analyzed by using the Likert scale which will be seen within the following table:

\begin{tabular}{clc}
\hline $\begin{array}{c}\text { Positive } \\
\text { Statement } \\
\text { Score }\end{array}$ & \multicolumn{1}{c}{ Statement } & $\begin{array}{c}\text { Negative } \\
\text { Statement } \\
\text { Score }\end{array}$ \\
5 & Strongly difficult & 1 \\
4 & Difficult & 2 \\
3 & Undecided & 3 \\
2 & Not difficult & 4 \\
1 & Strongly not & 5 \\
& difficult & \\
\hline
\end{tabular}

Table 4 Analysis of Information
The item of this research consists of 10 positive statements and 10 negative ones. Hence, if a respondent answers all the positive statements with strongly difficult together with all ten negative ones with strongly not difficult, they got 100 scores and also the one who answers all the positive statements with strongly not difficult together with all ten negative ones with strongly difficult will get 20 scores. So, the rating score ranges from 20 to 100 (interval 80). Since the questionnaire employs 5 levels/categories, the interval wont to determine the level/category of the respondents was 80:5=16. Accordingly, the rating score for every category ranges as shown within the tables as follows:

\begin{tabular}{cl}
\hline Score & \multicolumn{1}{c}{ Category } \\
$85-100$ & Strongly positive \\
$69-84$ & Positive \\
$52-68$ & Fairly positive (moderate) \\
$36-51$ & Negative \\
$0-35$ & Strongly negative \\
\hline & Table 5 Rating Score
\end{tabular}

\section{Findings}

In this section, the researcher presents the student's score on the target and essay test. The quick percentages of the target and test, the students' mean score, and analysis of the questioners.

1. The analysis of the students' achievement through objective and essay tests.

To determine the extent of the students' achievement through in learning 
simple present, the researcher gives some classification as follows:

\begin{tabular}{lc}
\hline Classification & Score \\
Excellent & $9.6-10$ \\
Very good & $8.6-9.5$ \\
Good & $7.6-8.5$ \\
Fairly good & $6.6-7.5$ \\
Fair & $5.6-6.5$ \\
Poor & $3.6-5.5$ \\
Very poor & $0-3.5$ \\
\hline \multicolumn{2}{l}{ Table 6 The Students' achievement through in learning } \\
\multicolumn{2}{c}{ simple present }
\end{tabular}

To know the score of every student the researcher gave the score of 10 for each item either objective or essay test, the researcher used formula as follows:

Score $=\frac{10 \times \text { correct answer }}{\text { Number of items } / 30}$

Note: $10=$ score for every item.

To know the common score, the entire score is split by two kinks of the test (objective and essay test)

To help the researcher to debate the info analysis, the result is presented within the following tables:

Item I

\begin{tabular}{|c|c|c|c|c|c|}
\hline \multirow{2}{*}{$\begin{array}{l}\text { Respond } \\
\text { ent }\end{array}$} & \multicolumn{2}{|c|}{$\begin{array}{l}\text { Number of } \\
\text { items }\end{array}$} & $\begin{array}{l}\text { Total } \\
\text { of }\end{array}$ & $\begin{array}{l}\text { Tot } \\
\text { al }\end{array}$ & $\begin{array}{l}\text { Ave } \\
\text { r- }\end{array}$ \\
\hline & Obje & essa & the & sco & age \\
\hline & $\mathrm{ct}$ & $\mathrm{y}$ & corre & re & scor \\
\hline & & & $\mathrm{ct}$ & & $\mathrm{e}$ \\
\hline & & & answ & & \\
\hline & & & er & & \\
\hline 1 & 2 & 3 & 8 & 9 & 10 \\
\hline 1 & 20 & 10 & 8 & 4 & 2 \\
\hline 2 & 20 & 10 & 11 & 7 & 3.5 \\
\hline
\end{tabular}

\begin{tabular}{|c|c|c|c|c|c|}
\hline 3 & 20 & 10 & 7 & 4 & 2 \\
\hline 4 & 20 & 10 & 10 & 8 & 4 \\
\hline 5 & 20 & 10 & 9 & 7 & 3.5 \\
\hline 6 & 20 & 10 & 16 & 11 & 5.5 \\
\hline 7 & 20 & 10 & 22 & 14. & 7.5 \\
\hline 8 & 20 & 10 & 24 & 5 & 8 \\
\hline 9 & 20 & 10 & 25 & 16 & 8.25 \\
\hline 10 & 20 & 10 & 12 & 16. & 4 \\
\hline 11 & 20 & 10 & 6 & 5 & 2 \\
\hline 12 & 20 & 10 & 6 & 8 & 2 \\
\hline 13 & 20 & 10 & 11 & 4 & 3 \\
\hline 14 & 20 & 10 & 5 & 4 & 2 \\
\hline 15 & 20 & 10 & 9 & 6 & 3 \\
\hline 16 & 20 & 10 & 10 & 4 & 3 \\
\hline 17 & 20 & 10 & 9 & 6 & 3 \\
\hline 18 & 20 & 10 & 10 & 6 & 3 \\
\hline 19 & 20 & 10 & 10 & 6 & 4 \\
\hline 20 & 20 & 10 & 24 & 6 & 7.75 \\
\hline 21 & 20 & 10 & 7 & 8 & 2 \\
\hline 22 & 20 & 10 & 12 & 15. & 4 \\
\hline 23 & 20 & 10 & 10 & 5 & 3 \\
\hline 24 & 20 & 10 & 16 & 4 & 5 \\
\hline 25 & 20 & 10 & 17 & 8 & 5 \\
\hline 26 & 20 & 10 & 9 & 6 & 3 \\
\hline 27 & 20 & 10 & 11 & 10 & 4 \\
\hline 28 & 20 & 10 & 20 & 10 & 6 \\
\hline 29 & 20 & 10 & 11 & 6 & 3.5 \\
\hline 30 & 20 & 10 & 16 & 8 & 5.5 \\
\hline 31 & 20 & 10 & 13 & 12 & 4 \\
\hline 32 & 20 & 10 & 9 & 7 & 2 \\
\hline 33 & 20 & 10 & 10 & 17 & 3.25 \\
\hline 34 & 20 & 10 & 10 & 8 & 3 \\
\hline
\end{tabular}




\begin{tabular}{llllll}
\hline 35 & 20 & 10 & 18 & 6 & 6 \\
36 & 20 & 10 & 9 & 6.5 & 3 \\
37 & 20 & 10 & 10 & 6 & 3 \\
38 & 20 & 10 & 10 & 12 & 2.5 \\
39 & 20 & 10 & 13 & 6 & 4.5 \\
40 & 20 & 10 & 9 & 6 & 3 \\
& & & & 5 & \\
& & & & 9 &
\end{tabular}

$\begin{array}{llllll}\text { Total } & 800 & 400 & 484 & 314 & 156\end{array}$

Table 7 The Students' Score Obtained Through Objective And Essay Test

This table indicates that the total average score of the students' achievement in learning simple present is 156 that obtained through objective and essay tests. Item 2

\begin{tabular}{|c|c|c|c|c|}
\hline No & Achievement & Score & Freq & Percen \\
\hline 1 & Excellent & $9.6-10$ & 0 & $0 \%$ \\
\hline 2 & Very good & $8.6-9.5$ & 0 & $0 \%$ \\
\hline 3 & Good & $7.6-8.5$ & 2 & $5 \%$ \\
\hline 4 & Fairly good & $6.6-7.5$ & 1 & $2.5 \%$ \\
\hline 5 & Fair & $5.6-6.5$ & 2 & $5 \%$ \\
\hline 6 & Poor & $3.6-5.5$ & 10 & $25 \%$ \\
\hline 7 & Very poor & $0-3.5$ & 25 & $62.5 \%$ \\
\hline & Total & & 40 & $100 \%$ \\
\hline
\end{tabular}

Table 8 Rate Percentage of the Students' Score

This table shows that none of the students got an excellent and very good score, 2 students (5\%) got a good score, 1 student $(2.5 \%)$ got a fairly good score, 2 students (5\%) got fair, 10 students (25\%) got poor, and 25 students $(62.5 \%)$ very poor score.

Item 3

\begin{tabular}{llccc}
\hline 1. & Excellent & $9.6-$ & 0 & $0 \%$ \\
2. & Very good & 10 & 0 & $0 \%$ \\
3. & Good & $8.6-$ & 4 & $10 \%$ \\
4. & Fairly good & 9.5 & 2 & $5 \%$ \\
5. & Fair & $7.6-$ & 2 & $5 \%$ \\
6. & Poor & 8.5 & 15 & $37.5 \%$ \\
7. & Very poor & $6.6-$ & 17 & $42.5 \%$ \\
& & 7.5 & & \\
& & $5.6-$ & & \\
& & 6.5 & & \\
& & $3.6-$ & & \\
& & 5.5 & & \\
& & $0-3.5$ &
\end{tabular}

Table 9 Rate Percentage of the Students' Score Obtained Through Objective Test.

This table shows that none of the students got an excellent and very good score, 4 students (10\%) got a good score, 2 students (5\%) got a fairly good score, 2 students $(5 \%)$ got a fair score, 15 students (37.5\%) got a poor score, and 17 students $(42.5 \%)$ got a very poor score.

Item 4

\begin{tabular}{llccc}
\hline No & Achievement & Score & Freq & Percen \\
1. & Excellent & $9.6-10$ & 0 & $0 \%$ \\
2. & Very good & $8.6-9.5$ & 0 & $0 \%$ \\
3. & Good & $7.6-8.5$ & 2 & $5 \%$ \\
4. & Fairly good & $6.6-7.5$ & 2 & $5 \%$ \\
5. & Fair & $5.6-6.5$ & 5 & $12.5 \%$ \\
6. & Poor & $3.6-5.5$ & 7 & $17.5 \%$ \\
7. & Very poor & $0-3.5$ & 24 & $60 \%$ \\
\multicolumn{2}{r}{ Total } & & $\mathbf{4 0}$ & $\mathbf{1 0 0} \%$ \\
\hline
\end{tabular}

Table 10 Rate Percentage of the Students' Score Obtained Through Essay Test.

This table shows that none of the students got excellent and really good scores, 2 students (5\%) got a good score, 2 students (5\%) got a fairly good score, 5 students $(12.5 \%)$ got a fair score, 7

\section{No. Achievement Score Freq Percen}


students $(17.5 \%)$ got a poor score, and 24 students $(60 \%)$ got a very poor score. Item 5 No

\begin{tabular}{|c|c|c|c|}
\hline No & $\begin{array}{c}\text { Kinds of } \\
\text { the test }\end{array}$ & $\begin{array}{c}\text { Total of } \\
\text { Final Score }\end{array}$ & $\begin{array}{c}\text { Average } \\
\text { Score }\end{array}$ \\
\hline 1. & Objectiv & 170 & 4.5 \\
\hline 2. & $\begin{array}{l}\text { e test } \\
\text { Essay } \\
\text { test }\end{array}$ & 144 & 3.6 \\
\hline & Total & 314 & 8.1 \\
\hline
\end{tabular}

Table 11 The Students' Final Score and Average Score Obtained Through Objective Test and Essay Test.

This table shows that the students' final score obtained through the objective essay test 144 , its average is 3.6. The total students' final score is 314 and total of the average score is 8.1. The students "mean score"

To find out the students means score, the researcher used the following formula:

$\mathrm{M}=\frac{\Sigma \mathrm{X}}{\mathrm{N}}$

Where:

$\mathrm{M}=$ The means score

$\Sigma \mathrm{X}=$ Students' total score

$\mathrm{N} \quad=$ Number of students

Calculation:

$\Sigma \mathrm{X}=156$

$\mathrm{N}=40$

$\mathrm{M}=3.9$

Analysis of the questionnaires

Item 6 test is 170 , its average score is 4.5 , and

\begin{tabular}{llcc}
\hline 1. & Interested & 18 & $45.0 \%$ \\
2. & Very interested & 9 & $22.5 \%$ \\
3. & Less interested & 7 & $17.5 \%$ \\
4. & Not interested & 6 & $15.0 \%$
\end{tabular}
Total

40
$100 \%$

Table 12 Whether or not the Students Interested toward english subject

This table indicated that 18 students (45.0\%) said interested toward English subject, 9 students $(22.5 \%)$ very interested, 7 students $(17.5 \%)$ less interested, and 6 students $(15.0 \%)$ said not interested toward English subject.

Item 7

\begin{tabular}{llcc}
\hline No. & \multicolumn{1}{c}{ Response } & Freq & Percentage \\
1. & Like & 15 & $37.5 \%$ \\
2. & Like very much & 8 & $20.0 \%$ \\
3. & Dislike & 12 & $30.0 \%$ \\
4. & $\begin{array}{l}\text { Dislike very } \\
\text { mush }\end{array}$ & 5 & $12.5 \%$ \\
& $\quad$ Total & 40 & $100 \%$ \\
\hline
\end{tabular}

Table 13 Whether or Not the Students like or dislike to study english

This table indicated that 15 students $(37.5 \%)$ said they like to study English, 8 students $(20.0 \%)$ said like, 12 students (30 $\%)$ said dislike, and 5 students (12.5\%) dislike very much to study English. Item 8

\begin{tabular}{llcc}
\hline No. & Response & Freq & Percentage \\
1. & Important & 21 & $52.5 \%$ \\
2. & Very important & 19 & $47.5 \%$ \\
3. & Less important & 0 & $0 \%$ \\
4. & Not important & 0 & $0 \%$ \\
& Total & 40 & $100 \%$ \\
\hline
\end{tabular}

Table 14 The Students response about the use of simple present tense.

This table indicated that 21 students

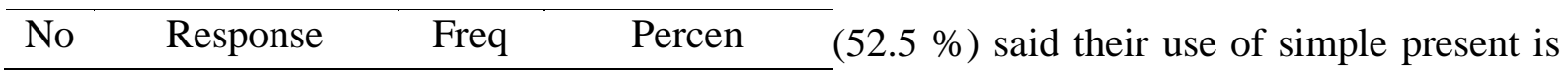
important to learn, 19 students (47.5\%) 
said very important, none of the students $(0$ $\%)$ said less important and none of the students $(0 \%)$ said not important.

Item 9

\begin{tabular}{llcc}
\hline No. & \multicolumn{1}{c}{ Response } & Freq & Percentage \\
1. & Easy to learn & 13 & $32.5 \%$ \\
2. & Very easy to learn & 0 & $0 \%$ \\
3. & Difficult to learn & 20 & $50 \%$ \\
4. & Very difficult to & 7 & $17.5 \%$ \\
& learn & & \\
& $\quad$ Total & 40 & $100 \%$ \\
\hline
\end{tabular}

Table 15 The Students Response about English Subject.

This table indicated that 13 students $(32.5 \%)$ said English subject is easy to learn, none of the students (0\%) said very easy to learn, 20 students $(50 \%)$ said difficult to learn, 7 students $(17.5 \%)$ said English is very difficult to learn.

Item 10

\begin{tabular}{llcc}
\hline No. & Response & Frequency & Percentage \\
1. & Reading & 9 & $22.5 \%$ \\
2. & Speaking & 18 & $45 \%$ \\
3. & Structure & 7 & $17.5 \%$ \\
4. & Listening & 3 & $7.5 \%$ \\
5. & No & 3 & $7.5 \%$ \\
& comment & & \\
& Total & 40 & $100 \%$ \\
\hline
\end{tabular}

Table 16 The part of English Subject the must be interested in the students.

This table indicated that 9 students $(22.5 \%)$ said interested in reading, 18 students (45\%) interested in speaking, 7 students $(17.5 \%)$ interested in structure, 3 students $(7.5 \%)$ interested in listening, and 3 students $(7.5 \%)$ who had no comment. Item 11

\begin{tabular}{lccc}
\hline No. & Response & Freq & Percentage \\
1. & Always & 16 & $40 \%$ \\
\hline
\end{tabular}

\begin{tabular}{llcc}
\hline 2. & Sometimes & 14 & $35 \%$ \\
3. & Seldom & 10 & $25 \%$ \\
4. & Never & 0 & $0 \%$ \\
& Total & 40 & $100 \%$ \\
\hline
\end{tabular}

Table 17 Whether or Not Students Paid Attention to the Teacher's Explanation on Teaching and Learning Process.

This table indicated that 16 students (40\%) said always, 14 students (35\%) said sometimes, 10 students ( $25 \%$ ) said seldom, and none of the students $(0 \%)$ said never. Item 12

\begin{tabular}{llcc}
\hline No. & Response & Freq & Percentage \\
1. & Ever & 19 & $47.5 \%$ \\
2. & Always & 0 & $0 \%$ \\
3. & Sometimes & 6 & $15 \%$ \\
4. & Never & 15 & $37 \%$ \\
& Total & 40 & $100 \%$ \\
\hline
\end{tabular}

Table 18 Whether or not their teacher and their parent always give the suggestion and motivation and for them to learn English.

This table indicated that 19 students $(47.5 \%)$ said ever, none of the students $(0$ $\%)$ said always, 6 students (15\%) said sometimes, 15 students (37\%) said never. Item 13

$\begin{array}{llcc}\text { No. } & \text { Response } & \text { Freq } & \text { Percentage } \\ \text { 1. } & \text { Often } & 8 & 20 \% \\ \text { 2. } & \text { Sometimes } & 17 & 42.5 \% \\ \text { 3. } & \text { Seldom } & 8 & 20 \% \\ \text { 4. } & \text { Never } & 7 & 17.5 \% \\ & \text { Total } & 40 & 100 \%\end{array}$

Table 19 Whether or not the students learn english on spear time.

This table indicated that 8 students (20\%) said often, 17 students $(42.5 \%)$ said sometimes, 8 students (20\%) said seldom, and seven students (17.5\%) said never.

Item 14

\begin{tabular}{llcc}
\hline No. & Response & Freq & Percentage \\
1. & Ever & 19 & $47.5 \%$ \\
\hline
\end{tabular}




\begin{tabular}{llcc}
\hline 2. & Always & 0 & $0 \%$ \\
3. & Sometimes & 14 & $35 \%$ \\
4. & Never & 7 & $17.5 \%$ \\
& Total & 40 & $100 \%$ \\
\hline
\end{tabular}

Table 20 Whether or Not the English teacher informed the student about the importance of mastering English structure.

This table indicated that 19 students $(47.5 \%)$ said ever none of the students $(0$ $\%)$ said always, 14 students (35\%) said sometimes, 7 students $(17.5 \%)$ said never. Item 15

\begin{tabular}{llcc}
\hline No. & Response & Freq & Percentage \\
1. & Ever & 24 & $60 \%$ \\
2. & Often & 0 & $0 \%$ \\
3. & Sometimes & 16 & $40 \%$ \\
4. & Never & 0 & $0 \%$ \\
& Total & 40 & $100 \%$ \\
\hline
\end{tabular}

Table 21 Whether or Not the English Teacher Explained the Students about the Use of Simple Present Tense.

This table indicated that 24 students (60\%) said ever explained, none of the students $(0 \%)$ said often, 16 students (40 $\%)$ said sometimes, and none of the students $(0 \%)$ said never explained.

Item 16

\begin{tabular}{llcc}
\hline No. & Response & Freq & Percentage \\
1. & Understand & 19 & $47.5 \%$ \\
2. & Very understand & 0 & $0 \%$ \\
3. & Less understand & 15 & $37.5 \%$ \\
4. & Not understand & 16 & $15 \%$ \\
& $\quad$ Total & 40 & $100 \%$ \\
\hline
\end{tabular}

Table 22 Whether or the students understand the use of simple present tense.

This table indicated that 19 students (47.5\%) said understand, none of the students $(0 \%)$ said very understand, 15 students $(37.5 \%)$ said less understand, and 6 students (15\%) said not understand.

\begin{tabular}{|c|c|c|c|}
\hline No. & Response & Freq & Percentage \\
\hline 1. & Have motivation & 8 & $20 \%$ \\
\hline 2. & Sometimes & 10 & $25 \%$ \\
\hline 3. & Lack & 13 & $32.5 \%$ \\
\hline 4. & motivation & 9 & $22.5 \%$ \\
\hline & $\begin{array}{l}\text { Have } \\
\text { motivation } \\
\text { Total }\end{array}$ & 40 & $100 \%$ \\
\hline
\end{tabular}

Table 23 Whether or the students understand the use of simple present tense.

This table indicated that 8 students (20 \%) said they have motivation, 10 students (25\%) said sometimes, 13 students $(32.5 \%)$ said lack of motivation, and 9 students $(22.5 \%)$ said have no motivation. Item 18

\begin{tabular}{llcc}
\hline No. & Response & Freq & Percentage \\
1. & Always & 9 & $72.5 \%$ \\
2. & Sometimes & 11 & $27.5 \%$ \\
3. & Seldom & 0 & $0 \%$ \\
4. & Never & 0 & $0 \%$ \\
& Total & 40 & $100 \%$ \\
\hline
\end{tabular}

Table 24 Whether or Not the Students got difficulties in Learning English.

This table indicates that 29 students (72.5\%) said always, 11 students $(27.5 \%)$ said sometimes, none of the students $(0 \%)$ said seldom, and none of the students $(0 \%)$ said never.

Item: This one is an open-ended item. This item refers to the difficulties of the student in learning simple tense. Considering the students' responses the researcher summarizes that 34 students $(85$ $\%)$ were still confused about the employment of easy tense and 6 students $(15 \%)$ said failed to understand the 
employment of straightforward tense. And most of them didn't understand about tense.

Item: This item is also open-ended. This item informs the students' suggestions to other English teachers. And most of the students offered some suggestions for the English teacher, as follows:

- The teacher should give suggestions and motivation for college kids in learning English.

- The teacher should explain in detail about the utilization of easy present and also tenses generally.

- The teacher should give more tasks or exercises for the student to extend the student's memories.

- The teacher should actively the student on teaching and learning process.

- The teacher should explain the fabric by using the variation method or interesting method.

- The teacher should correct the students' mistakes specifically the students' tasks or worksheets.

- The teacher should pay more attention to the student who gets difficulties in learning English.

\section{DISCUSSION}

The Students' Achievement: Based on the research on the target and essay test had been given to the second-year students of MAN Dompu. The researcher concluded that almost all of the students' score is "very poor", this can be proved that the students' mean score is (3.6) the student score may be described as follows: Rate percentage of the students' score, none of the student $(0$ $\%)$ got an excellent and really good score, 2 students (5\%) got a good score, 1 student $(2.5 \%)$ got fairly good, 2 students $(5 \%)$ got fair, 10 students (25\%) got poor, and 25 students $(62.5 \%)$ good very poor score. The students' score obtained through objective test is (4.5), none of the students got an excellent and really good score, 4 students (10\%) got a good score, 2 students (5\%) got fairly good, 2 students $(5 \%)$ got fair, 15 students (37.5\%) got poor, and 17 students $(42.5 \%)$ good very poor score. The students' score obtained through essay test is (3.6), none of the students $(0 \%)$ got an excellent and very good score, 2 students $(5 \%)$ got a good score, 2 students $(5 \%)$ got fairly good, 5 students (12.5\%) got fair, 7 students $(17.5 \%)$ got poor, and 24 students (60\%) good very poor score.

The difficulties faced by the student in learning simple tense: Considering the information analysis of the questionnaires, the researcher found some problems faced by the second year students of MAN Dompu in learning simple present as follows: the students were fairly interested toward English subject; English is very 
difficult for them; a people teacher never gave suggestion and motivation for the student; Teachers never informed the student about the importance of learning English especially simple present tense; Students have low motivation in learning English; nation teacher never paid attention for the student who gets difficulties in learning English; Lack of stimulation for the students in learning English; and students have the low ability.

\section{CONCLUSION}

Based on the results of the research described above, the following conclusions can be drawn:

1. The results of the analysis of data obtained through questionnaires, showed that there were several problems faced by the second grade students of MAN Dompu in learning English, namely students were quite interested in English subjects; English is very difficult for them; the instructor never gives advice and motivation to students; The teacher never tells the students about the importance of learning English, especially the simple present tense; Students have low motivation in learning English; English teachers never pay attention to students who have difficulty learning English; Lack of stimulation for students in learning English; and Students have low abilities.

2. The results of data analysis obtained through objective tests and essays are very lacking, this can be proven by the average score of students, namely 3.9 , the test results indicate that students' abilities are very low in understanding English material, especially in the use of the simple present tense.

\section{REFERENCES}

Arikunto, Suharsini. (1991), Prosedur Penelitian: Suatu Pendekatan Praktik. Jakarta: Rineka Cipta.

A.S Hornby (1989). Oxford Advanced Learners Dictionary of Current English, (Oxford: Oxford University Press.

Best john W. \& James V Khan. (1986). Research in Education. Sidney: Prentice-Hall of Australia Pty.

Gay, LR. (1986). Educational Research: Competencies for Analysis and Application. Columbus: Charles E. Merrill Publishing Company.

George E Wishon and Julia M. Burks(1980). Let's Write English, (North York: Van Nostrand Reinhold Ltd. 
Michael Swan (1948). Basic English Usage, (New York: Oxford University Press.

Swick, Ed. (2010). English Verbs and Essentials of Grammar for ESL Learners. United States: McGrawHill.

Sutrisno Hadi (2002), Metodologi Research I, Yogyakarta: Andi Offset.

Polmusvita Rez and Muhd. Al Hafizh (2019) Students' Ability and Difficulties in Comprehending Simple Sentence in English at First Grade of SMA Adabiah Padang. Universitas Negeri

Padang, Padang, Indonesia 